緊急血管造影にて迅速に診断し切除した回盲部動静脈奇形の 1 例

\author{
健康保険八代総合病院外科, 熊本市民病院外科* \\ 倉本正文蓮尾友伸石原光二郎 \\ 池嶋聡岩槻政晃島田信也*
}

消化管の動静脈奇形は比較的稀な疾患で，下血の原因精査の際に偶然発見されること がほとんどである. 今回われわれは, 大量下血にて発症した回盲部の動静脈奇形の 1 例 を経験した。患者は 50 歳, 男性で,下血にて来院. 来院時は血圧が $68 / 49 \mathrm{mmHg}$, 顔面蒼 白でショック状態であった. 大腸内視鏡検查で回盲弁直上に粘膜下腫窇と思われる隆起 を認めたが，明らかな出血源の同定はできなかった，続いて腹部血管造影を施行したと ころ, 回結腸動脈の末梢に㹡張した血管叢を認め, 早期に静脈まで造影された。よって 回盲部の動静脈奇形からの出血と診断し, 回盲部切除術を施行した. 術後経過は良好て あった．大量下血をきたした症例において内視鏡検查で出血源が同定できない場合は， 積極的な血管造影検查が有効であると思われた。

索引用語：動静脈奇形 (AVM), 大腸, 緊急血管造影

\section{緒 言}

動静脈奇形（arteriovenous malformation：以下， AVM と略記)は四肢に多く,消化管では比較的稀であ るか，消化管出血の原疾患として重要な疾患である。 症状は下血が最も多く，出血源の精查の際に初めて発 見されることがほとんどである.今回われわれは，緊 急血管造影にて回盲部の AVM と診断し, 早急に切除 しえた症例を経験したので報告する。

$$
\text { 症例 }
$$

患者：50歳, 男性.

主訴：下血.

既往歴：C 型肝炎, 糖尿病, 高血圧.

現病歴：以前上り C 型肝炎, 糖尿病, 高血圧にて内 科通院加療中であった. 平成11年 7 月 4 日より少量の 血便があったが様子をみていた，7月10日に大量の下 血あったため来院. 即日入院となった。

入院時現症：血圧 $68 / 49 \mathrm{mmHg}$, 脈拍 $120 / \mathrm{min}$, 意識 は清明. 顔面は荅白でョック状態であった。腹部は 平坦で, 腹満, 圧痛などは認めなかった。

検査成績：末梢血にて Hb $6.1 \mathrm{~g} / \mathrm{dl}$ と著明な貧血を

2005 年 4 月22日受付 2005 年 5 月17日採用 〈所属施設住所〉

テ866-8660 八代市松江城町 2-26
認めた．生化学検査では軽度の低タンパク血症（TP $5.9 \mathrm{~g} / \mathrm{dl}$ )，低アルブミン血症（alb $3.2 \mathrm{~g} / \mathrm{dl}$ )，高血糖 (193mg/dl) を認めたものの，それ以外は目立った異 常所見はなく，出血時間，凝固時間も正常であった。

内視鏡検査所見：胃内視鏡検查を施行したが，特に 異常はなく出血源も認めなかった．大腸内視鏡検査で は，回盲弁直上に立ち上がりがなだらかな粘膜の隆起 を認め，粘膜下腫瘍が疑われた。回盲部を中心に血液 の貯留あったものの検查時に出血はなく，明確な出血 源の同定はできなかった（図 1 ).

引き続いて, 出血源精査のため緊急腹部血管造影を 施行した。

腹部血管造影所見：上腸間膜動脈造影にて回結腸動 脈の末梢に抬張した動脈を認め, 動脈相後期では nidus と思われる血管叢を認めた，回結腸静脈は早期 に造影され，これは大腸内視鏡で認められた粘膜下腫 瘍の位置と一致していた（図 2 )。

以上より, 回盲部の AVM からの出血と診断し, 回 盲部切除術を施行した.

切除標本肉眼所見：切除後は粘膜下の隆起は，ほほ 消失し腫瘤は同定できなかった。おそらく，腫瘤内の 血液が流出してしまったためであると思われた（図 3).

病理組織学所見：病変部の粘膜下層を中心に血管の 


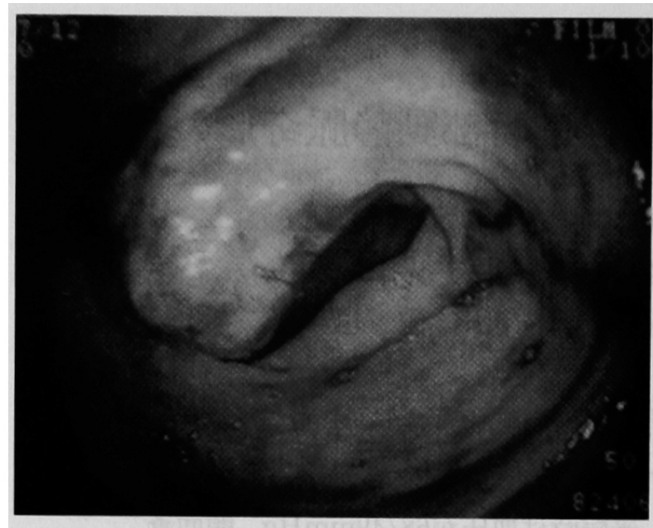

図 1 大腸内視镜所見：回盲弁の直上に粘膜下腫痽 様の隆起を認めた．腸管内に血液の貯留は認めた が，明らかな出血点は確認できなかった。

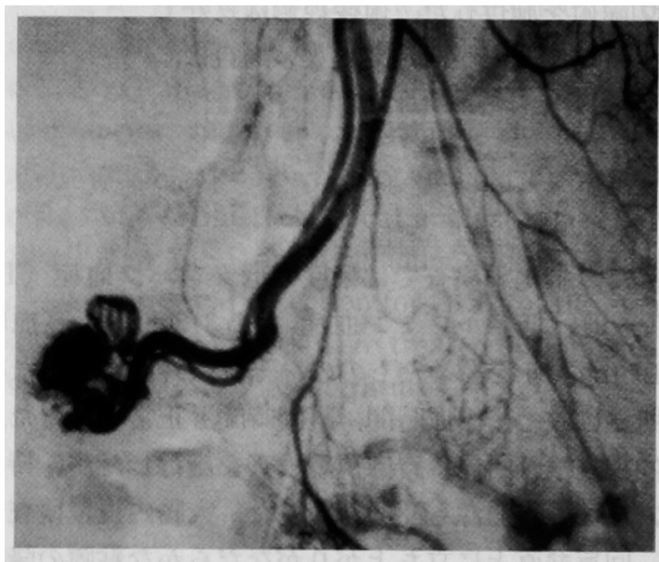

図 2 腹部血管造影所見：上腸間膜動脈造影にて回 結腸動脈の末梢に nidus と思われる血管叢を認め た。また回結腸静脈は早期に造影された。

增生，拡張を認め，内腔には血栓を伴っていた。 また 一部に動脈と静脈の交通も認められ，AVM の所見と 合致していた（図4).

術後の経過は良好で, 術後14日で退院となった。 考 察

消化管の AVM は原因不明の消化管出血の鑑別診 断にあげられ，比較的稀な疾患てある．消化管出血の 原因精査の際に初めて発見されることがほとんどであ る. 画像診断が得られにくいため, 出血源の同定に苦 虑することが多く、致命的になることもある゙. 消化管

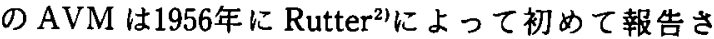
れ，1960年には Margulis ら゙かが血管造影によって明ら かにした．本症の血管造影所見としては，(1)流入動脈

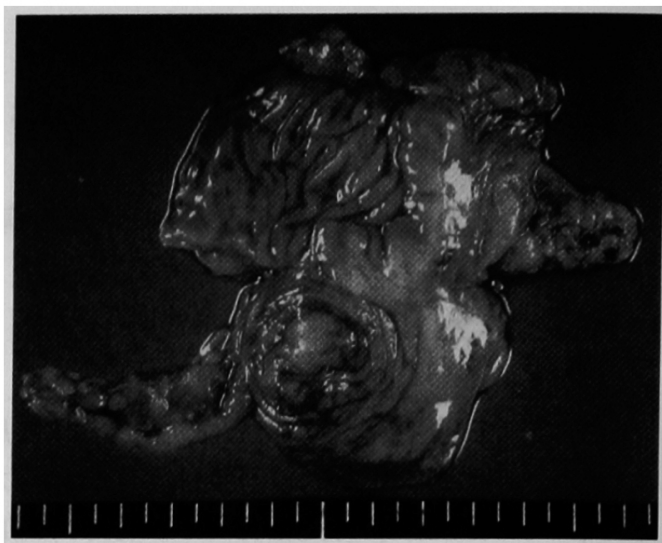

図 3 切除標本肉眼所見：切除標本では，腄痛は内 部の血液が流出し虚脱していた。
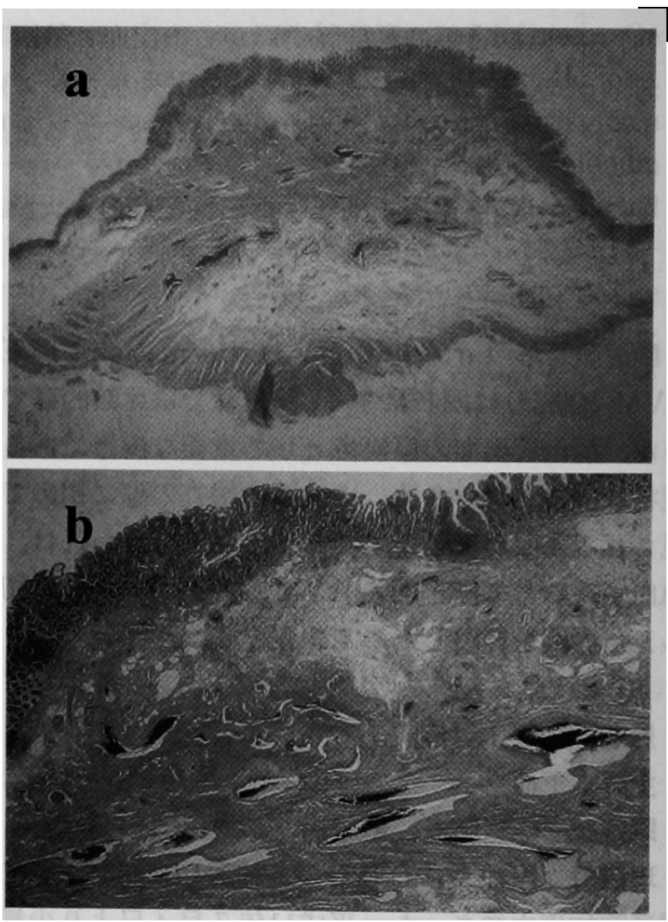

図 4 病理組織学的所見：粘膜下層に血管の増生お よび搪張を認めた (HE 染色 $\mathbf{a} ： \times 4, \mathrm{~b}: \times 20)$

の拡張，(2)異常血管の集簇 (nidus)，(3)流出静脈の早期 描出, (4)静脈相後期まで透延する流出静脈の造影, (5)

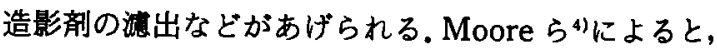
発生部位は上腸間膜動脈領域に多く，盲腸～右半結腸 が $78 \%$, 空腸 $10.5 \%$ ，回腸 $5.5 \%$ ，十二指腸 $2.5 \%$ ，直 腸 $0.9 \%$ とされている.また, Moore らは AVM を臨床 的に 3 つの型に分類している. I 型は限局性の小病変 
で後天性と考えられ，高齢者に多くみられる。この type がもっとも多く報告されており，部位は回盲部か ら右結腸に多い.II 型は小腸に多発し，比較的若年者 に多く先天的要素が強く、びまん性の大病変で墏膜側 からも確認できることもある。III型は Rendu-OslerWeber 病に属するもので, 消化管以外にも多発性に病 変がみられ，家族性に発症する。本症例は回盲部の孤 立性の比較的小さな病変であり, I 型に属するものと 考えられた。

消化管 AVM の診断は内視鏡検查では確認できな い場合も多く，本症例でも大腸内視鏡検查にて回盲部 に粘膜下腫晼を確認はしたが, 確定診断にまでは至ら なかった. そこで本症例では，内視鏡検査に引き続い て緊急血管造影を施行した。腸間膜動脈造影で回盲 部にAVMを認めたため,これを出血源と診断し緊急 手術を施行した．来院から約 7 時間で迅速な治療を成 しえたという点で意義があるものと考えられた。

消化管出血の出血源精查という点では99mTc-HAS を使用した出血シンチグラム検查も有用といえる．血 管造影では $0.5 \mathrm{ml} / \mathrm{min}$ 以上の出血がないと検出され ないとされているのに対し，出血シンチグラム検查で は0.05 0.3ml $/ \mathrm{min}$ の出血で検出でき, 感度が高く出 血部診断には有用であるとの報告もある ${ }^{51}$. しかし病 巣の質的診断ができない，あるいは，検査の時点で出 血していないと描出されないため間歇的に出血してい るような場合には無効なこともある。また出血部の大 まかな同定はできるが, 開腹手術において槳膜面から 確認できない病巣では, 部位同定に難渋したりの, 過大 切除の可能性が示唆される.

一方, 血管造影検査は病変によっては質的診断が可 能であり，塞栓療法により止血することもできる7/8). また塞栓に使用したコイルや, マイクロカテーテルな どを留置し，それをマーカーとして手術を行えば，術 中の正確な部位診断を可能にするという点で，消化管 出血の症例では有効な検查であるといえる ${ }^{91-11 !}$ 。われ われは消化管出血の症例で内視鏡検查で出血源が同定 できなかった場合や，同定できても止血が困難な場合 には，積極的に腹部血管造影検查を行うようにしてお クこのような対処をすることにより，重篤化する前 に適切な治療を行うことができると考えている.
結語

今回われわれは大量下血にて発症した回盲部 AVM の1例を経験した. 緊急血管造影により迅速に診断し， 切除しえた。

\section{文献}

1）東原秀行, 岡崎正敏, 木村史郎他：下部消化管の 動静脈奇形の画像診断と IVR. 臨画像 $18: 1318$ $-1324,2002$

2) Rutter AG: Submucous telangiectasis of the colon. Lancet 2 : 1077-1079, 1956

3) Margulis AR, Heinbecker $P$, Bernard HR, et al: Operative mesenteric arteriography in the search for the site of bleeding in unexplained gastrointestinal hemorrhage. Surgery $48: 534$ $-539,1960$

4) Moore JD, Thompson NW, Appelman HD, et al : Arteriovenous malformation of the gastrointestinal tract. Arch Surg 111:381-389, 1976

5）小室安宏, 佐田尚宏, 川口米栄他: 出血部位の判 定に核医学検査が有用であった盲腸動静脈奇形の 1 例. 外科 $63: 110-115,2001$

6）谷口 巧, 山田成寿, 富永聡子他：術中内視鏡検 查にて出血部位を同定しえた空腸動静脈奇形破裂 の1 例. 日救急医会誌 $9: 14-17,1998$

7）関根忠一, 松井 茂, 岩松 宏他: 動脈塞栓術が 奏効した大腸動静脈奇形の 1 例. Gastroenterol Endosc 45:1144-1149, 2003

8) 土川貫裕, 長谷川直人, 菅野紀明他：動脈塞栓術 後に再発を繰り返した大腸動静脈奇形の 1 例. 日 臨外会誌 $64: 1939-1943,2003$

9）山本貴章, 河地茂行, 川原英之他：血管内コイル をマーカーとして腹腔鏡補助下に切除しえた空腸 動静脈奇形の 1 例. 日消外会誌 $32: 1235-1239$, 1999

10）劉嘉忠，谷聡，萩原良輔他：消化管出血を 絽り返す微小回腸動静脈奇形の 1 例. 日消病会誌 $97: 1401-1403,2000$

11）金井俊和, 西山雷祐, 阿部仁郎他：空腸動静脈奇 形の 1 例. 日臨外会誌 $64: 1386-1388,2003$ 


\title{
A PATIENT WITH ARTERIOVENOUS MALFORMATION OF THE CECUM DIAGNOSED BY EMERGENT ABDOMINAL ANGIOGRAPHY FOLLOWED BY A PROMPT SUCCESSFUL SURGICAL TREATMENT
}

\author{
Masafumi KURAMOTO, Tomonobu HASUO, Koujirou ISHIHARA \\ Satoshi IKESHIMA, Masaaki IWA TSUKI and Shinya SHIMADA* \\ Department of Surgery, Yatsushiro Health Insurance General Hospital \\ -Department of Surgery, Kumamoto Municipal Hospital
}

Gastrointestinal arteriovenous malformation (AVM) is a relatively uncommon disease, and is almost found by the investigation of GI bleeding. We report a case of cecal AVM with massive hemorrhage. A 50-year-old man was admitted to the hospital because of massive melena and hemorrhagic shock. Although colonoscopic examination detected a submucoal tumor of the cecum, obvious bleeding point was not identified. Emergent abdominal angiography, however, revealed a cecal AVM. Ileo-cecal resection was quickly and successfully performed. For the patient presenting with massive melena, emergent abdominal angiography is highly recommended when the bleeding point is not identified by endoscopic examination. 